\title{
POPULASI MAKROFAUNA, MESOFAUNA, DAN TUBUH BUAH FUNGI EKTOMIKORIZA PADA TEGAKAN Shorea leprosula DI HUTAN PENELITIAN GUNUNG DAHU BOGOR \\ (Population of Macrofauna, Mesofauna, and Ectomycorrhizae's Fruit Body at Shorea leprosula stand in Gunung Dahu Forest Research, Bogor)
}

\section{Tasya Chotimah $^{1^{*}}$, Basuki Wasis ${ }^{2}$, dan/and Henti Hendalastuti Rachmat ${ }^{3}$}

${ }^{1}$ Departemen Silvikultur Tropika, Sekolah Pascasarjana, IPB University, Jl. Lingkar Akademik Kampus IPB Dramaga, 16680, Bogor, Jawa Barat, Indonesia

${ }^{2}$ Fakultas Kehutanan, IPB University, Jl. Lingkar Akademik Kampus IPB Dramaga, 16680, Bogor, Jawa Barat, Indonesia

${ }^{3}$ Pusat Penelitian dan Pengembangan Hutan, Jl. Gunung Batu No. 5 P.O. Box 165, Bogor 16610, Kota Bogor, Jawa Barat, Indonesia, 0251-8633234, 7520067/8638111

\begin{tabular}{|c|c|}
\hline Info artikel: & ABSTRACT \\
\hline $\begin{array}{l}\text { Keywords: } \\
\text { Ectomychorrhiza, } \\
\text { macrofauna, } \\
\text { mesofauna, } \\
\text { Shorea leprosula } \\
\text { plantation }\end{array}$ & $\begin{array}{l}\text { Shorea leprosula Miq. is a highly economic dipterocarp tree species planted in the Gunung } \\
\text { Dahu Forest Research (GDFR) at various planting distances. GDFR was established in } \\
1997 \text { - } 2000 \text { as an effort to restore landscape while conserving dipterocarp genetic } \\
\text { resources. The purpose of this study was to quantify the population of soil macrofauna and } \\
\text { mesofauna and to determine the fruit body of ectomycorrhiza species at those S. leprosula } \\
\text { plots at a various spacing distance and unplanted plots. The sample collection of } \\
\text { macrofauna and mesofauna species was carried out in the litter using a hand sorting } \\
\text { method while on the soil using a berlese funnel. The identification was carried out at the } \\
\text { Forest Entomology Laboratory, IPB University. Ectomychorriza observation was } \\
\text { conducted by the census in each observation circle plot with a radius of } 17.8 \text { m by observing } \\
\text { the presence of a fruiting body on the forest floor. This study identified } 13 \text { macrofauna and } \\
\text { mesofauna species dominated by worms and ants; } 10 \text { species of ectomycorrhiza fruit body } \\
\text { with the most commonly found species were Russula genera. }\end{array}$ \\
\hline \multirow{2}{*}{$\begin{array}{l}\text { Kata kunci: } \\
\text { Ektomikoriza, } \\
\text { makrofauna, } \\
\text { mesofauna, } \\
\text { tegakan Shorea } \\
\text { leprosula }\end{array}$} & $\overline{\mathbf{A B S}}$ \\
\hline & $\begin{array}{l}\text { Shorea leprosula Miq. adalah salah satu jenis Dipterocarpaceae yang memiliki nilai } \\
\text { ekonomi dan ditanam di Hutan Penelitian Gunung Dahu (HPGD) pada berbagai jarak } \\
\text { tanam. HPGD didirikan pada tahun } 1997-2000 \text { sebagai upaya untuk memulihkan lanskap } \\
\text { dengan melestarikan sumber daya genetik dipterokarpa. Tujuan penelitian ini adalah untuk } \\
\text { mengukur populasi makrofauna, mesofauna tanah, dan tubuh buah fungi ektomikoriza } \\
\text { dalam plot } S \text {. leprosula pada berbagai jarak tanam dan plot kontrol yang tidak ditanami. }\end{array}$ \\
\hline $\begin{array}{l}\text { Riwayat artikel: } \\
\text { Tanggal diterima: } \\
\text { 30 Januari 2020; } \\
\text { Tanggal direvisi: } \\
2 \text { April 2020; } \\
\text { Tanggal disetujui: } \\
13 \text { April } 2020\end{array}$ & $\begin{array}{l}\text { Pengumpulan sampel makrofauna dan mesofauna dilakukan di serasah menggunakan } \\
\text { metode hand sorting sementara di tanah menggunakan corong berlese. Identifikasi } \\
\text { dilakukan di Laboratorium Entomologi Hutan, IPB. Pengamatan fungi ektomikoriza } \\
\text { dilakukan dengan sensus di setiap plot lingkaran dengan jari-jari } 17,8 \mathrm{~m} \text {. Penelitian ini } \\
\text { menunjukkan terdapat } 13 \text { jenis makrofauna dan mesofauna yang didominasi oleh cacing, } \\
\text { semut, dan } 10 \text { jenis tubuh buah ektomikoriza dengan jenis yang paling banyak ditemukan } \\
\text { adalah genus Russula. }\end{array}$ \\
\hline
\end{tabular}

Editor: Asep Hidayat, S.Hut, M.Agr, Ph.D

Korespondensi penulis: Tasya Chotimah* (E-mail: tasyachtmh19@gmail.com)

Kontribusi penulis: TC: Pengambilan data lapangan, identifikasi jenis, analisa hasil dan penulisan manuskrip; BW: Merancang kerangka penelitian, analisa hasil dan penulisan manuskrip; HHR: Merancang kerangka penelitian, fasilitasi lokasi penelitian, analisa hasil dan penulisan manuskrip. 


\section{PENDAHULUAN}

Keragaman hayati tanah bisa didefinisikan secara sederhana sebagai bentuk berbagai kehadiran organisme yang menghabiskan semua waktu atau sebagian lingkaran hidupnya di dalam tanah atau permukaan tanah (termasuk permukaan serasah dan kayu-kayu lapuk). Pengelompokan yang paling mudah dan paling dikenal sampai saat ini dilakukan berdasarkan ukuran tubuh, dan terbagi menjadi tiga kategori fauna tanah yaitu makrofauna, mesofauna, dan mikrofauna (Herdina, Noli, \& Chairul, 2013; Juniarti, Herawatiningsih, \& Burhanuddin, 2017). Fauna tanah banyak tersebar di daerah tropis yang memiliki biodiversitas tinggi dan memiliki banyak peranan (Sugiyarto, 2000; Sugiyarto, Efendi, Mahajoeno, Sugiti, Handayanto, \& Agustina, 2007; Sutoyo, 2010; Wihartono, 2015).

Fauna tanah memiliki banyak dampak dan manfaat melalui perannya dalam proses fisik maupun biokimia tanah. Diantara manfaat tersebut adalah memengaruhi laju pembentukan tanah, mineralisasi, humifikasi bahan organik, teksur tanah dan konsistensinya, makroporositas total, laju infiltrasi dan karakteristik retensi air-tanah (Apriyadi, 2014; Sugiyarto, 2000; Sugiyarto et al., 2007; Simanjuntak, \& Waluyo, 1982; Suin, 2012). Fauna tanah juga menciptakan kondisi habitat menjadi lebih memungkinkan untuk ditinggali oleh berbagai jenis organisme lain (Gunawan, \& Prasetyo, 2013; Sugiyarto, 2000). Terlepas dari begitu banyaknya manfaat yang bisa dihasilkan dari keberadaan fauna tanah, berbagai aspek fauna tanah masih belum banyak dieksplorasi terutama di daerah tropis (Leksono, 2011; Nurrohman, Rahardjanto, \& Wahyuni, 2018).

Perubahan komposisi dan struktur vegetasi dalam satu proses suksesi bentang lahan telah banyak dipelajari, namun demikian pengetahuan yang berhubungan dengan perubahan dalam komposisi dan populasi fauna tanah masih sangat terbatas (Destaranti, Sulistyani, \& Yani, 2017; Nurrohman et al., 2018; Sugiyarto, 2000; Sugiyarto et al., 2007). Upaya restorasi sebuah bentang lahan tidak hanya bisa diukur dengan adanya perubahan dalam struktur dan komposisi vegetasi yang tumbuh tetapi juga dari perubahan dalam keseluruhan fungsi ekosistem termasuk didalamnya adalah komposisi dan populasi fauna. Oleh karenanya indikasi sebuah keberhasilan kegiatan restorasi harus bisa menunjukan keselarasan antara dinamika komposisi dan struktur vegetasi dengan tingkat keterpulihan komunitas edafis yang ada di dalamnya (Araújo, Fernandes, Paulo, \& Gomes, 2010; Jouquet, Bottinelli, Shanbag, Bourguignoon, Traore, \& Abbasi, 2014; Lutfi, \& Antono, 2017; Wortley, Hero, \& Howes, 2013).

Dipterocarpaceae merupakan keluarga pohon dominan yang menempati bentang hutan hujan tropis Indonesia dengan nilai ekonomis yang tinggi baik dari produk kayu maupun non kayu yang dihasilkannya (Maria, Manurung, \& Sisillia, 2016; Nono, Diba, \& Fahrizal, 2017). Populasi dipterokarpa telah mengalami penurunan yang signifikan dalam beberapa dekade terakhir akibat adanya faktor eksternal (pembalakan liar, kebakaran hutan, kerusakan habitat, konversi lahan, bencana alam) maupun faktor internal (pertumbuhan relatif lambat, perkembangan buah relatif lama, masa berbuah tidak teratur dengan rentang yang cukup panjang, dan buah rekalsitran (Atmoko, Arifin, \& Priyono, 2010; Erizilina, Pamoengkas, \& Darwo, 2019; Purwaningsih, 2004; Septria, Fernando, \& Tavita, 2018; Sukarno, Listiyowati, Rahayu, \& Nara, 2019).

Jenis-jenis dalam keluarga dipterokarpa diketahui memiliki asosiasi yang kuat dengan berbagai jenis fungi diantaranya adalah ektomikoriza (Hakim, Halwany, \& Rachmanadi, 2019; Karmilasanti, \& Maharini, 2016; Rohmaya, Mardji, \& Sukartiningsih, 2011; Ulfa et al., 2019). Fungi 
ektomikoriza berasosiasi dengan tumbuhan tingkat tinggi pada berbagai jenis hutan beriklim sedang dan tropis (Brearley, 2012; Sato, Tanabe, \& Toju, 2015). Ektomikoriza memiliki peran dalam perlindungan dan ketahanan akar terhadap serangan berbagai jenis patogen, cekaman abiotik di sekitar rhizosfer, serta meningkatkan kapasitas penyerapan unsur hara dan air oleh akar (Alamsjah, \& Husin, 2010). Ektomikoriza dapat dijumpai pada tegakan dipterokarpa di berbagai ekosistem hutan baik hutan sekunder maupun hutan primer (Alamsjah, \& Husin, 2010; Karmilasanti, \& Maharani, 2016; Mardji, 2010; Ulfa et al., 2019).

Hutan Penelitian Gunung Dahu (HPGD) merupakan hutan penelitian meranti yang dibangun pada 1997 - 2000 dengan luas total kawasan mencapai lebih dari 250 hektar. HPGD dibangun dengan konsep hutan tanaman meranti multi jenis dengan pengaturan pada beberapa jarak tanam dan teknik penanaman. Total jumlah jenis yang ditanam baik pada blok eksperimen maupun blok koleksi terdapat lebih dari 20 jenis dengan luasan dan perlakuan yang berbeda tergantung ketersediaan bibit pada saat penanaman. Salah satu jenis meranti yang ditanam di hutan penelitian ini adalah jenis Shorea leprosula (Rachmat, \& Fambayun, 2019; Subiakto, Rachmat, \& Sakai, 2016). HPGD telah bertransformasi dari sebuah bentang lahan tidak produktif menjadi tegakan hutan meranti (Rachmat, Fambayun, Yulita, \& Susilowati, 2020; Subiakto et al., 2016). Dilihat dari komposisi dan struktur vegetasi maka upaya restorasi bentang lahan di HPGD telah berhasil. Namun demikian, belum ada studi yang mengupas sejauh mana keberhasilan upaya restorasi bentang lahan ini bisa memberikan perubahan terhadap komunitas edafis yang ada di dalamnya, khususnya dari aspek keberadaan dan kelimpahan populasi makrofauna dan mesofauna tanah serta keberadaan tubuh buah ektomikoriza. Oleh karena itu, tujuan penelitian ini adalah menguanti- fikasi populasi makrofauna dan mesofauna tanah serta mengetahui jenis-jenis tubuh buah ektomikoriza yang berasosiasi pada plot tegakan S. leprosula pada berbagai jarak tanam. Sebagai pembanding dengan kondisi yang telah dilakukan penanaman maka dilakukan pengamatan yang sama pada plot yang tidak ditanami.

\section{BAHAN DAN METODE}

\section{A. Waktu dan Lokasi Penelitian}

Penelitian dilaksanakan di Hutan Penelitian Gunung Dahu (HPGD) pada bulan Oktober - Desember 2019. Secara umum, HPGD memiliki curah hujan 2500 $-2700 \mathrm{~mm} /$ tahun, topografi berbukit dan curam antara $15-45 \%$ dengan ketinggian sekitar 550 - $900 \mathrm{mdpl}$. Jenis tanah di HPGD adalah latosol coklat kemerahan (inceptisol) serta memiliki iklim tipe B dengan kelembaban relatif $80 \%$ dengan suhu rata-rata $30{ }^{\circ} \mathrm{C}$ (Subiakto, \& Sakai, 2007).

HPGD merupakan plot uji penanaman meranti yang berasal dari sistem perbanyakan massal stek pucuk KOFFCO (Subiakto et al., 2016) maupun benih dengan luas lebih dari $250 \mathrm{Ha}$. Total luas yang ditanami meranti sebesar 160,7 Ha, terdiri dari plot percobaan seluas 75 Ha dan plot koleksi jenis Dipterokarpa seluas $85,7 \mathrm{Ha}$ yang ditanam pada tahun 1997 - 2000. Penelitian ini dilakukan pada plot uji jarak tanam sistem penanaman total (total planting) jenis $S$. leprosula dengan jarak tanam $2 \mathrm{~m} \times 2 \mathrm{~m}, 3 \mathrm{~m} \times 3 \mathrm{~m}$, $4 \mathrm{~m} \times 4 \mathrm{~m}$, dan $5 \mathrm{~m} \times 5 \mathrm{~m}$, dengan ukuran plot $100 \mathrm{~m}$ x $100 \mathrm{~m}$ (1 Ha). Di HPGD plot uji jarak tanam $S$. leprosula terdiri dari tiga ulangan untuk masing-masing jarak tanam dengan masing-masing luas $1 \mathrm{Ha}$.

Sebagai pembanding maka pengamatan dan penelitian dilakukan juga di dalam areal HPGD yang tidak dilakukan penanaman meranti selama periode 1997 - 2000. Adapun luasan rumpang terbuka yang tidak dilakukan penanaman berukuran \pm 3 Ha dan berada pada jarak 1.000 meter dari Petak 1 ( $2 \mathrm{~m}$ x $2 \mathrm{~m}$ ). Peta lokasi penelitian disajikan pada Gambar 1 . 


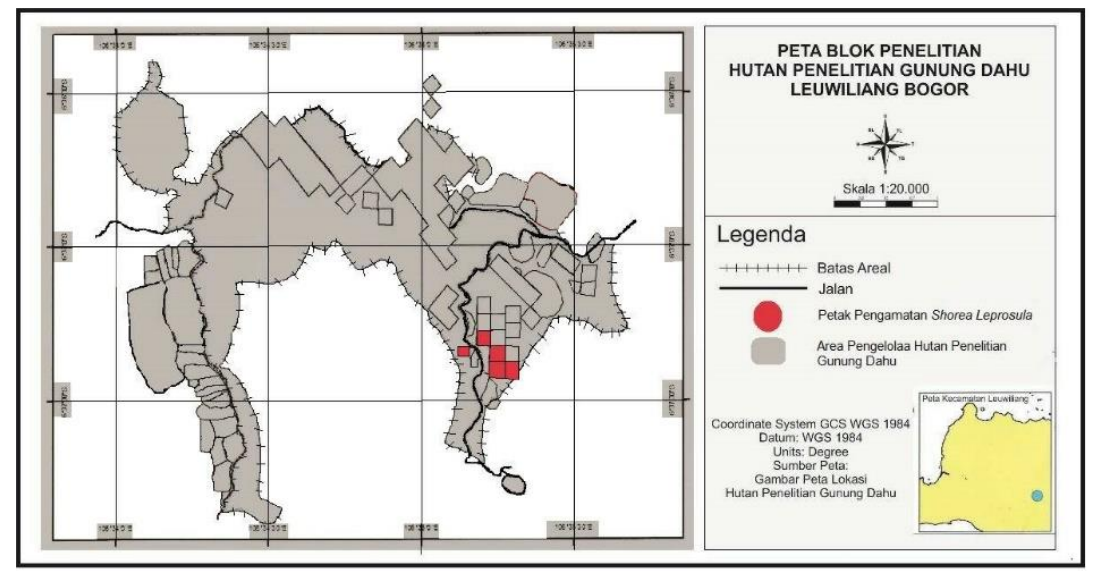

Gambar (Figure) 1. Lokasi penelitian di Hutan Penelitian Gunung Dahu, Bogor (Research location at Gunung Dahu Forest Research, Bogor)

\section{B. Bahan dan Alat}

Alat yang digunakan adalah pita ukur, pita jahit, penggaris, phi band, Global Position System (GPSmap 60CSx), kompas, mikroskop stereo, optilab, ring tanah, hygrometer, botol film, loop, lakban, kardus, kamera, golok, cangkul, kantong plastik bening, nampan plastik, spidol, cawan petri, pinset, kertas label, buku identifikasi serangga (Borror, Triplehorn, \& Johnson, 1996), lampu 40 watt, corong berlese. Bahan yang digunakan yaitu contoh tanah, alkohol $70 \%$, dan aquades.

\section{Metode Penelitian}

Koleksi dan identifikasi pengamatan tubuh buah ektomikoriza, makrofauna dan mesofauna di HPGD dilakukan di bawah tegakan $S$. leprosula dengan jarak tanam $2 \mathrm{~m} \times 2 \mathrm{~m}$ (petak 1), $3 \mathrm{~m} \times 3$ $\mathrm{m}$ (petak 2), $4 \mathrm{~m} \times 4 \mathrm{~m}$ (petak 5), $5 \mathrm{~m} \mathrm{x} 5$ $\mathrm{m}$ (petak 4), dan satu areal lahan yang tidak ditanami berada dalam kawasan HPGD. Areal kosong tersebut dijadikan sebagai pembanding dengan kondisi tegakan $S$. leprosula dan memiliki jarak sekitar $1 \mathrm{~km}$ dari lokasi plot $S$. leprosula jarak tanam $2 \mathrm{~m}$ x $2 \mathrm{~m}$.

Pengamatan untuk makrofauna dan mesofauna dilakukan pada setiap jarak tanam, kemudian menentukan tiga plot lingkaran dengan jari-jari 17,8 m pada petak jarak tanam. Di dalam plot lingkaran dibentuk sub-plot berukuran $40 \mathrm{~cm}$ x 40 $\mathrm{cm}$ dengan kedalaman $0-5 \mathrm{~cm}$. Metode pengambilan makrofauna dan mesofauna dilakukan pada serasah menggunakan hand sorting sedangkan pada tanah menggunakan dua metode yaitu hand sorting (Suin, 2012) dan corong berlese (Cahyani, Aminatun, \& Putra, 2017). Identifikasi makrofauna dan mesofauna dilakukan di Laboratorium Entomologi Hutan, IPB dengan merujuk pada metode/buku. Identifikasi makrofauna dan mesofauna dilakukan pada mikroskop dan optilab, selanjutnya identifikasi taksonomi pada serangga menggunakan beberapa kunci identifikasi yaitu pengenalan serangga yang mengacu pada (Borror et al., 1996), Bugguide.net dan Antkey.org. Identifikasi jenis lain dapat mengacu pada (Anwar, \& Ginting, 2013).

Pengamatan tubuh buah ektomikoriza dilakukan pada setiap petak pengamatan (petak 1, 2, 5, 4, dan petak non penanaman) dengan membuat tiga plot lingkaran pada masing-masing petak pengamatan dengan jari-jari 17,8 m. Metode yang dilakukan adalah sensus di setiap plot pengamatan (Karmilasanti, \& Maharini, 2016; Kasongat, Muzna, Gofur, \& Ponisri, 2019). Identifikasi morfologi dilakukan pada tubuh buah segar fungi ektomikoriza (Brundrett, Bougher, Dell, 
Grove, \& Malajczuk, 1996), dan memotret tubuh buah. Tubuh buah diambil dengan hati-hati menggunakan sudip di bawah tajuk tegakan meranti. Tubuh buah yang di-koleksi diambil dari zona humus pada kedalaman $\pm 10 \mathrm{~cm}$ dari permukaan tanah, dan selanjutnya dimasukkan dalam kantong kertas untuk diidentifikasi di Laboratorium Mikoriza, Fakultas Kehutanan IPB. Identifikasi jenis fungi ektomikoriza menggunakan beberapa literatur yang dilengkapi dengan foto-foto berwarna. Foto keadaan fungi yang masih segar dibandingkan dengan yang ada di literatur serta memastikan bahwa data morfologi seperti tudung, bau, dan bentuknya termasuk fungi ektomikoriza (Laessoe, \& Lincoff, 1998; Lestari, \& Suryanto, 2013).

\section{Analisis Data}

Analisis data dilakukan dengan menghitung indeks kekayaan jenis Margalef (Margalef, 1958), indeks keanekaragaman jenis (Barbour, Burk, \& Pitts, 1987), dan indeks kemerataan jenis (Magurran, 2004).

\section{HASIL DAN PEMBAHASAN}

\section{A. Makrofauna dan Mesofauna}

Pengamatan makrofauna dan mesofauna di HPGD dilakukan pada saat awal musim penghujan dan selama satu periode pengamatan. Makrofauna dan mesofauna memiliki banyak peranan penting terhadap suatu habitat (Amazonas, Viani, Rego, Camargo, Fujihara, \& Valsechi, 2018; Ibrahim, 2014; Risman, \& Ikhsan, 2017). Aktivitas makrofauna dan mesofauna dipengaruhi oleh jumlah jenis dan individu pada suatu habitat (Angi, \& Wiati, 2017; Arief, 2001; Putra, 2012). Hasil identifikasi makrofauna dan mesofauna yang terdapat pada HPGD disajikan pada Tabel 1.

Berdasarkan Tabel 1 jumlah jenis dan individu fauna tanah di bawah tegakan dengan beberapa jarak tanam menunjukkan hasil yang cukup bervariasi. Berdasarkan metode yang digunakan, metode hand sorting menghasilkan keragaman jenis dan jumlah individu terbanyak. Makrofauna dan mesofauna yang ditemukan pada petak kontrol lebih rendah dibandingkan petak lainnya.

Perkembangan keberhasilan restorasi dari aspek pertumbuhan vegetasi yang ditanam juga diikuti dengan perkembangan pada populasi komunitas edafis yang ada pada habitat tersebut (makrofauna dan mesofauna), dalam artian bahwa pada areal yang ditanami (dengan jarak tanam tertentu) akan memiliki populasi fauna tanah yang lebih beragam daripada areal kontrol (yang tidak ditanami). Makrofauna dan mesofauna tanah menanggapi perubahan vegetasi di sepanjang suksesi sekunder, sehingga membantu peningkatan biomassa tanaman dan peningkatan bahan organik. Kondisi areal yang sudah ditanami berbeda dengan areal yang terbuka seperti tingkat kelembaban dan suhu yang dapat memengaruhi aktivitas makrofauna dan mesofauna (Patang, 2010; Sugiyarto et al., 2007; Vasconcellos, Segat, Bonfirm, Baretta, \& Cardoso, 2013; Wibowo, \& Slamet, 2017).

Tipe penggunaan suatu lahan dapat memengaruhi keberadaan makrofauna dan mesofauna. Semakin tinggi populasi tanaman per satuan luas, maka semakin besar persaingan unsur hara antar tanaman, sehingga hasil jumlah jenis dan individu makrofauna dan mesofauna yang diperoleh akan beragam. Perbedaan jarak tanam karena pengaruh vegetasi, biomassa tanaman, peningkatan bahan organik maupun sifat lingkungan lainnya memengaruhi keragaman tersebut (Arief, 2001; Risman, \& Ikhsan, 2017; Tarmeji, Shanti, \& Patmawati, 2018; Widyati, 2013). Dengan semakin tingginya tutupan kanopi, biomassa, dan serasah di hutan jumlah fauna tanah yang ditemukan umumnya lebih banyak dan beragam, sehingga menjaga kondisi iklim mikro lebih stabil (Nurrohman et al., 2018; Sugiyarto et al., 2007; Wibowo, \& Slamet, 2017). Jumlah jenis dan individu banyak 
ditemukan pada jarak tanam $4 \mathrm{~m} \times 4 \mathrm{~m}$ dibandingkan $2 \mathrm{~m} \times 2 \mathrm{~m}, 3 \mathrm{~m} \times 3 \mathrm{~m}$, dan 5 $\mathrm{m} \times 5 \mathrm{~m}$. Jika dibandingkan, petak yang ditanami dengan petak kontrol memiliki perbedaan dalam jumlah makrofauna dan mesofauna yang ditemukan. Hal ini mengidentifikasikan bahwa keberhasilan restorasi dari aspek pertumbuhan vegetasi sejalan dengan perkembangan komunitas edafisnya.

Dilihat dari perbedaan dua metode yang digunakan, metode hand sorting menghasilkan jumlah individu dan jenis yang ditemukan lebih banyak dibandingkan dengan corong berlese. Hal ini disebabkan karena pada metode corong berlese tidak ditemukan cacing sebagai akibat kematian cacing karena adanya pemanasan lampu, sehingga yang terekstraksi hanya jenis-jenis dari mesofauna. Sedangkan kekurangan dari metode hand sorting yaitu kurangnya ketelitian dalam pencarian fauna tanah pada skala mesofauna bahkan mikrofauna dan pergerakan fauna tanah (Risman, \& Ikhsan, 2017). Namun dari segi kepraktisannya metode hand sorting lebih praktis digunakan di lapangan dan tidak memerlukan alat (Suin, 2012).

Makrofauna tanah mempunyai peranan penting dalam dekomposisi bahan organik tanah guna menyediakan unsur hara. Keberadaan mesofauna tanah dalam tanah sangat bergantung pada ketersediaan energi dan sumber makanan untuk melangsungkan hidupnya, seperti bahan organik dan biomassa hidup yang semuanya berkaitan dengan aliran siklus karbon dalam tanah (Achmad, \& Aji, 2016; Arief, 2001; Hilwan, \& Handayani 2013; Riniarti, \& Bintoro, 2018; Purwanto, Wawan, \& Wardati, 2017), sehingga keberadaan mereka dapat mendukung pertumbuhan dari S. leprosula.

Populasi fauna tanah berbeda pada berbagai kondisi. Sebagai contoh, keragaman fauna tanah seperti pada areal hasil restorasi hutan di Brazil lebih tinggi dibanding keragaman fauna tanah pada kondisi sebelum dilakukannya restorasi, yang didominasi oleh jenis semut dan rayap (Amazonas et al., 2018). Perbedaan kondisi abiotik tempat tumbuh dan vegetasi yang ada di dalam suatu bentang lahan menciptakan preferensi tersendiri bagi komunitas fauna tanah tertentu (Nurrohman et al., 2018; Martala, \& Maya, 2014; Sugiyarto et al., 2007). Sebagai contoh, Hymenoptera dan Orthopteran dapat ditemukan pada agroekosistem rumput di zona kars (Bautista, Castelazo, \& Robles, 2009), kelimpahan cacing tanah relatif tidak dipengaruhi oleh jenis vegetasi dan distribusinya pun merata jika dibandingkan dengan kaki seribu (Hilwan, \& Handayani, 2013), kemiringan dapat memengaruhi tingkat keragaman fauna tanah terutama pada lahan miring agroforestri (Peritika, Sugiyarto, \& Sunarto, 2012). Di HPGD sendiri keberadaan fauna tanah pada berbagai kondisi petak yang memiliki perbedaan perlakuan silvikultur ditunjukan pada Tabel 2 .

Jenis $O$. denticulata merupakan spesies endemik (semut) di wilayah Indomalaya dan spesies epigaeic yang habitat utamanya di permukaan tanah, sehingga banyak ditemukan di seluruh petak pengamatan. Spesies semut tersebut ditemukan juga di Bogor dan daerah lain di Jawa (Hilwan, \& Handayani, 2013; Tarmeji et al., 2018). Jenis semut lainnya yang ditemukan yaitu $A$. gracilipes, $M$. pharaonis, $P$. dentata, namun jenis tersebut tidak ditemukan di setiap jarak tanam. A. gracilipes mendominasi pada bagian tanah. A. gracilipes sering dijumpai pada lingkungan yang lembab dan tidak terpapar oleh sinar matahari secara langsung seperti di bawah pohon, di bawah tumpukan daun kering, di dalam rongga akar dan batang tanaman bambu serta di bawah tumpukan sampah (Apriyadi, 2014). Famili Formicidae umum ditemukan juga di lahan gambut pasca kebakaran (Hakim et al., 2019). 
Tabel (Table) 1. Jumlah individu dan jenis makrofauna dan mesofauna (Number of individuals and species of macro and mesofauna)

\begin{tabular}{|c|c|c|c|c|c|c|c|}
\hline \multirow{2}{*}{ No } & \multirow{2}{*}{$\begin{array}{c}\text { Jarak tanam } \\
\text { (Planting distance) }\end{array}$} & \multicolumn{3}{|c|}{$\begin{array}{c}\text { Jumlah jenis } \\
\text { (Number of species) }\end{array}$} & \multicolumn{3}{|c|}{$\begin{array}{c}\text { Jumlah individu } \\
\text { (Number of Individual) }\end{array}$} \\
\hline & & $\begin{array}{c}\text { Serasah } \\
\left.(\text { Litter })^{*}\right)\end{array}$ & $\begin{array}{l}\text { Tanah } \\
(\text { Soil)*) }\end{array}$ & $\begin{array}{c}\text { Tanah } \\
(\text { Soil })^{* *)}\end{array}$ & $\begin{array}{l}\text { Serasah } \\
\left.(\text { litter })^{*}\right)\end{array}$ & $\begin{array}{l}\text { Tanah } \\
\left.(\text { Soil })^{*}\right)\end{array}$ & $\begin{array}{c}\text { Tanah } \\
(\text { Soil })_{* *)}\end{array}$ \\
\hline 1 & $2 \mathrm{~m} \times 2 \mathrm{~m}$ & 4 & 5 & 3 & 9 & 13 & 10 \\
\hline 2 & $3 \mathrm{~m} \times 3 \mathrm{~m}$ & 5 & 3 & 3 & 12 & 22 & 8 \\
\hline 3 & $4 \mathrm{mx} 4 \mathrm{~m}$ & 5 & 4 & 4 & 24 & 19 & 19 \\
\hline 4 & $5 \mathrm{~m} \times 5 \mathrm{~m}$ & 4 & 3 & 2 & 12 & 31 & 3 \\
\hline \multirow[t]{2}{*}{5} & Kontrol (Control) & 3 & 4 & 1 & 4 & 17 & 3 \\
\hline & Total & 21 & 19 & 13 & 61 & 102 & 43 \\
\hline
\end{tabular}

*) Metode hand sorting (Hand sorting method), ${ }^{* *)}$ Metode corong berlese (Berlese funnel method)

Tabel (Table) 2. Keberadaan populasi makrofauna dan mesofauna (The presence of macrofauna and mesofauna populations)

\begin{tabular}{|c|c|c|c|c|c|c|}
\hline \multirow{2}{*}{ No } & \multirow{2}{*}{$\begin{array}{c}\text { Jenis } \\
\text { (Species) }\end{array}$} & \multicolumn{5}{|c|}{ Jarak tanam (spacing distance) } \\
\hline & & $2 \mathrm{~m} \times 2 \mathrm{~m}$ & $3 \mathrm{~m} \times 3 \mathrm{~m}$ & $4 \mathrm{~m} \times 4 \mathrm{~m}$ & $5 \mathrm{~m} \times 5 \mathrm{~m}$ & $\begin{array}{l}\text { Kontrol } \\
(\text { Control }) \\
\end{array}$ \\
\hline 1 & $\begin{array}{l}\text { Odontomachus denticulata } \\
\text { (semut) (Ant) }\end{array}$ & $\checkmark$ & $\checkmark$ & $\checkmark$ & $\checkmark$ & $\checkmark$ \\
\hline 2 & $\begin{array}{l}\text { Lumbricus terrestris (cacing) } \\
\text { (warm) }\end{array}$ & $\checkmark$ & $\checkmark$ & $\checkmark$ & $\checkmark$ & $\checkmark$ \\
\hline 3 & $\begin{array}{l}\text { Paracoccus marginatus } \\
\text { (kutu) (tick) } \\
\text { Subterranean termites }\end{array}$ & $\checkmark$ & $\checkmark$ & $\checkmark$ & $\checkmark$ & - \\
\hline 4 & $\begin{array}{l}\text { (rayap) (termite) } \\
\text { Anoplolepis gracilipes }\end{array}$ & $\checkmark$ & $\checkmark$ & $\checkmark$ & $\checkmark$ & - \\
\hline 5 & $\begin{array}{l}\text { (semut) (ant) } \\
\text { Monomorium pharaonis }\end{array}$ & $\checkmark$ & $\checkmark$ & $\checkmark$ & - & - \\
\hline 6 & $\begin{array}{l}\text { (semut) (ant) } \\
\text { Ground beetle (kumbang) }\end{array}$ & $\checkmark$ & - & $\checkmark$ & - & - \\
\hline 7 & $\begin{array}{l}\text { (beetle) } \\
\text { Brachypelma smithi (laba- }\end{array}$ & $\checkmark$ & - & - & - & $\checkmark$ \\
\hline 8 & $\begin{array}{l}\text { laba) (spider) } \\
\text { Blattella germanica (kecoa }\end{array}$ & - & $\checkmark$ & - & $\checkmark$ & - \\
\hline 9 & $\begin{array}{l}\text { tanah) (ground cockroach) } \\
\text { Ophyiulus pilosus (kaki }\end{array}$ & - & $\checkmark$ & - & $\checkmark$ & - \\
\hline 10 & $\begin{array}{l}\text { seribu) (millipide) } \\
\text { Pheidole dentata (semut) }\end{array}$ & - & $\checkmark$ & $\checkmark$ & - & - \\
\hline 11 & $\begin{array}{l}\text { (ant) } \\
\text { Atractomorpha crenulata }\end{array}$ & - & - & $\checkmark$ & - & - \\
\hline 12 & $\begin{array}{l}\text { (belalang) (grasshoppe) } \\
\text { Scolopendra cingulata }\end{array}$ & - & - & - & - & $\checkmark$ \\
\hline 13 & (kelabang) (centipede) & - & - & - & - & $\checkmark$ \\
\hline
\end{tabular}

Menurut Hölldobler \& Wilson (1990), semut memiliki peranan yang sangat penting di ekosistem sebagai detritivore (pemakan bangkai atau organisme lain), penyerbuk, pembuat airator tanah, predator. Selain itu, semut juga dapat dijadikan indikator kesuburan tanah (Hasyimuddin, Syahribulan, \& Usman, 2017). Jumlah dan komposisi semut pada suatu kawasan juga mengindikasikan kesehatan suatu ekosistem, sekaligus memberikan informasi aktivitas semut terhadap habitat atau organisme lain (Apriyadi, 2014; 
Haneda, \& Yuniar, 2015; Hilwan, \& Handayani, 2013). Data hasil (Tabel 2) menunjukkan ditemukannya berbagai jenis semut dengan karakteristik yang berbeda-beda.

Menurut Apriyadi (2014), $M$. pharaonis sering ditemukan di dalam tanah. Secara morfologis jenis ini memiliki warna tubuh kekuningan atau cokelat muda sampai merah, serta memiliki rambut tegak yang jarang pada tubuhnya. Sedangkan $P$. dentata banyak ditemukan di dalam kayu dan serasah. $L$. terrestris merupakan jenis cacing yang ditemukan pada berbagai jarak tanam. Makrofauna seperti cacing berperan dalam siklus energi dalam ekosistem (Hilwan, \& Handayani, 2013). Serasah dianggap sebagai sumber makanan yang paling baik bagi cacing tanah karena karbohidratnya relatif tinggi dan rendah kandungan lignoselulosenya. Cacing juga dapat meningkatkan porositas pada tanah karena sering membuat lubang pada tanah untuk tempat tinggal (Borror et al., 1996; Putra, 2012; Sugiyarto et al., 2007)

Cacing tanah sangat sensitif terhadap kadar keasaman tanah. Ke-asaman tanah bisa dianggap sebagai faktor pembatas dalam penyebaran cacing tanah dan menentukan jumlah cacing tanah di suatu daerah (Simanjuntak, \& Waluyo, 1982; Simatupang, Niswati, \& Yusnaini 2015; Sugiyarto et al., 2007). Kelembaban tanah yang ideal untuk pertumbuhan cacing tanah adalah $15-30 \%$. Temperatur yang diperlukan untuk pertumbuhan cacing tanah sekitar $15-25^{\circ} \mathrm{C}$. Cacing merupakan indikator kesubur-an suatu tanah dapat hidup pada semua kelas tekstur tanah, kecuali pada tanah berpasir, dengan rentang $\mathrm{pH}$ tanah ideal 6,0 - 7,2 (Apriyadi, 2014; Suin, 2012; Tarmeji et al., 2018). Lapisan tanah dengan kedalaman $0-10 \mathrm{~cm}$ memiliki kelembaban yang lebih sesuai untuk cacing (Firmansyah, Suparman, Harimin, Wigena, \& Subowo, 2014; Hilwan, \& Handayani, 2013; Wibowo, \& Slamet, 2017).
Jenis $S$. termites ditemukan pada petak yang ditanami meranti. Rayap merupakan salah satu dekomposer yang berguna bagi senyawa organik karena peranannya dalam mempercepat proses rehabilitasi fisik dan kimia tanah (Hilwan, \& Handayani, 2013; Ngatiman, 2014; Pranoto, \& Latifah, 2016). Keberadaan rayap dilaporkan terdapat pada tegakan $S$. leprosula dan Eucalyptus tetrodonta. Selain peran positif sebagai dekomposer, rayap memiliki peran dalam penurunan kualitas tegakan hutan. Apabila jumlah rayap dalam suatu ekosistem tinggi mengakibatkan kerak tanah pada suatu pohon yang menutupi kulit pohon berupa alur-alur, rayap juga mengambil makanan berupa selulosa. Namun tingkat kematian pada pohon masih tergolong rendah (Ngatiman, 2014; Ngatiman, \& Cahyono, 2017; Tarmeji et al., 2018).

Selain memiliki risiko terhadap kualitas tegakan meranti, secara ekologis rayap berperan dalam proses perbaikan agregat tanah, penyetabil bahan organik tanah, penyebaran, aerasi tanah, porositas tanah, membantu proses humifikasi dan pelepasan unsur $\mathrm{N}$ dan $\mathrm{P}$ dalam tanah. Keberadaan rayap tanah banyak ditemui di berbagai areal yang produktif ataupun tegakan yang pertumbuhannya subur (Pranoto, \& Latifah, 2016).

Jenis $P$. marginatus merupakan jenis kutu yang umumnya hidup pada bagian tumbuhan seperti serasah. Namun demikian, apabila jumlah kutu ini terlalu banyak dapat menyebabkan kerusakan pada tanaman. $O$. pilosus merupakan jenis kaki seribu cenderung hidup di permukaan tanah sehingga selalu membutuhkan perlindungan. Kaki seribu mampu mencerna sendiri beberapa material tumbuhan, terutama beberapa jenis protein dan gulagula sederhana (Sugiyarto et al., 2007). Jenis ini hanya ditemukan pada dua petak pengamatan. Selain kaki seribu, jenis kumbang, laba-laba, dan kecoa tanah juga hanya ditemukan pada dua petak pengamatan. 
Pada petak kontrol ditemukan fauna tanah dengan jumlah jenis dan individu yang lebih rendah. Pada petak kontrol juga ditemukan jenis belalang dan kelabang yang tidak dijumpai pada plot lain. Ditemukannya belalang dan kelabang diduga karena petak kontrol tidak tertanami dengan tegakan meranti sehingga komunitas tumbuhan yang ada lebih menyerupai sebagai semak belukar dengan beberapa rumpun bambu liar sebagai salah satu komponennya. Komunitas makrofauna dan mesofauna yang dilaporkan ada pada areal semak belukar adalah belalang, kumbang, kelabang, bekicot, semut hitam, rayap, cacing, semut merah, dan laba-laba (Arief, 2001; Hilwan, \& Handayani, 2013; Tarmeji et al., 2018).

Kondisi keterbukaan lahan di areal kosong jauh lebih tinggi dibanding tegakan meranti. Keterbukaan lahan tersebut bisa menjadi penyebab meningkatnya laju aliran permukaan, erosi tanah dan sedimentasi serta menurunnya tingkat kesuburan dan stabilitas lahan (Ardhana, 2011; Fuady, Satriawan, \& Mayani, 2014; Tarmeji et al., 2018). Akibatnya, keragaman dan aktivitas makrofauna dan mesofauna juga berbeda. Faktor edafis mengalami perkembangan seiring dengan adanya perubahan tutupan lahan seperti tekstur dan struktur tanah, sehingga memengaruhi keberadaan fauna tanah (Hilwan, \& Handayani, 2013; Suin, 2012) Selain itu, suhu tanah juga sangat menentukan proses terjadinya dekomposisi bahan organik tanah (Suin, 2012). Nilai indeks kekayaan jenis, keanekaragaman jenis, dan kemerataan jenis makrofauna dan mesofauna pada petak pengamatan dapat dilihat pada Tabel 3.

Apabila dilihat dari keseluruhan, indeks kekayaan yang tertinggi ditemukan pada pengambilan makrofauna dan mesofauna di bagian serasah dengan metode hand sorting pada petak $3 \mathrm{~m} \mathrm{x} 3$ m. Indeks kekayaan jenis antara yang ditanami dengan yang tidak ditanamai tidak memiliki perbedaan yang banyak, kecuali pada metode corong berlese. Pada petak kontrol terlihat hasil yang mencolok yaitu nilai indeks kekayaan jenis adalah 0 . Hal ini disebabkan, jumlah jenis yang ditemukan hanya terdapat satu jenis, sehingga memengaruhi nilai indeks kekayaan jenis, kemerataan jenis, dan keanekaragaman jenis (Suin, 2012).

Tabel (Table) 3. Nilai indeks kekayaan jenis (DMg), indeks keanekaragaman jenis (H'), dan indeks kemerataan jenis (E) makrofauna dan mesofauna (The value of species richness index (Dmg), species diversity index (H'), and species evenness index (E) of macro and mesofauna)

\begin{tabular}{|c|c|c|c|c|c|c|c|c|c|c|}
\hline \multirow[b]{2}{*}{ No } & \multirow{2}{*}{$\begin{array}{c}\text { Jarak } \\
\text { tanam } \\
\text { (Planting } \\
\text { distance })\end{array}$} & \multicolumn{3}{|c|}{$\mathrm{DMg}$} & \multicolumn{3}{|c|}{$\mathrm{H}^{\prime}$} & \multicolumn{3}{|c|}{$\mathrm{E}$} \\
\hline & & $\begin{array}{l}\text { Serasah } \\
\left.(\text { litter })^{*}\right)\end{array}$ & $\begin{array}{l}\text { Tanah } \\
(\text { soil)*) }\end{array}$ & $\begin{array}{c}\text { Tanah } \\
(\text { soil)**) }\end{array}$ & $\begin{array}{l}\text { Serasah } \\
(\text { litter })^{*)}\end{array}$ & $\begin{array}{c}\text { Tanah } \\
\left.(\text { soil })^{*}\right)\end{array}$ & $\begin{array}{c}\text { Tanah } \\
\left.(\text { soil })^{* *}\right)\end{array}$ & $\begin{array}{l}\text { Serasah } \\
(\text { litter })^{*)}\end{array}$ & $\begin{array}{c}\text { Tanah } \\
\left.(\text { soil })^{*}\right)\end{array}$ & $\begin{array}{c}\text { Tanah } \\
(\text { soil)**) }\end{array}$ \\
\hline 1 & $2 \mathrm{~m} \times 2 \mathrm{~m}$ & 1,365 & 1,559 & 0,869 & 1,215 & 1,327 & 0,898 & 0,876 & 0,824 & 0,817 \\
\hline 2 & $3 \mathrm{~m} \times 3 \mathrm{~m}$ & 1,611 & 0,647 & 0,962 & 1,474 & 0,893 & 0,974 & 0,916 & 0,813 & 0,887 \\
\hline 3 & $4 \mathrm{~m} \times 4 \mathrm{~m}$ & 1,259 & 1,019 & 1,019 & 1,412 & 1,091 & 1,386 & 0,877 & 0,787 & 1,000 \\
\hline 4 & $5 \mathrm{~m} \times 5 \mathrm{~m}$ & 1,207 & 0,582 & 0,910 & 0,983 & 1,018 & 0,637 & 0,709 & 0,927 & 0,918 \\
\hline 5 & $\begin{array}{l}\text { Kontrol } \\
\text { (control) }\end{array}$ & 1,443 & 1,059 & 0 & 1,040 & 0,955 & 0 & 0,946 & 0,689 & 0 \\
\hline
\end{tabular}

*) Metode hand sorting (Hand sorting method), ${ }^{* *)}$ Metode corong berlese (Berlese funnel method) 
Berdasarkan Tabel 3 terlihat bahwa nilai kemerataan jenis relatif seragam (berada pada nilai $0,70 \leq \mathrm{E} \geq 1$ ) dan dapat dikatakan kondisi penyebaran jenis relatif stabil (Husamah, Rahardjanto, \& Hudha, 2017). Nilai kemerataan tertinggi dihasilkan dengan metode corong berlese pada jarak tanam $4 \mathrm{~m} \mathrm{x} 4 \mathrm{~m}$ pada bagian tanah sebesar 1,000 (tergolong tinggi). Nlai kemerataan yang tinggi menandakan bahwa suatu jenis memiliki keberadaan yang merata pada suatu ekosistem yang diamati (Magurran, 2004).

Nilai keanekaragaman $(\mathrm{H})$ tertinggi diperoleh dengan metode hand sorting pada jarak tanam $3 \mathrm{~m} \times 3 \mathrm{~m}$ di bagian serasah yaitu 1,474. Keanekaragaman jenis akan berubah dan berbeda seiring berjalannya waktu dan terjadi alih fungsi dari kondisi tempat tersebut (Arief, 2001; Jeffries, 1997). Pada belukar muda 1,85 dan muda 1,15, hutan sekunder 2,18 (Hilwan, \& Handayani, 2013), dan pada hutan primer tropis 1.96 (Mahendra, Riniarti, \& Niswati, 2017). Keanekaragaman di HPGD memiliki nilai yang lebih rendah dibandingkan areal lainnya. Hal tersebut diduga karena fauna tanah masih berada pada kedalaman lebih dari 5 $\mathrm{cm}$, pergerakan fauna tanah yang aktif pada saat pengamatan, dan rendahnya nilai indeks keanekaragaman juga sangat dipengaruhi oleh pH (Suin, 2012).

\section{B. Ektomikoriza}

Pengamatan dan identifikasi ektomikoriza yang tumbuh di HPGD dilakukan pada awal musim penghujan. Koleksi dan identifikasi tubuh buah ektomikoriza hanya merefleksikan keberadaan pada saat pengamatan. Untuk melihat dinamika populasi dan keragaman ektomikoriza yang tumbuh di HPGD memerlukan observasi dan identifikasi frekuentif yang diambil pada berbagai kondisi musim. Namun demikian, pengamatan tubuh buah ektomikoriza yang dilakukan pada penelitian ini bukan tidak memiliki arti karena hasilnya bisa dijadikan data awal untuk observasi lanjutan yang lebih terperinci dan detail. Tabel 4 berikut menunjukan hasil pengamatan jumlah individu, jenis, dan suku dari tubuh buah ektomikoriza yang dikoleksi pada saat penelitian dilakukan.

Berdasarkan Tabel 4, jumlah jenis maupun jumlah individu tubuh buah ektokimoriza yang teridentifikasi di HPGD bervariasi untuk setiap plot pada jarak tanam berbeda. Plot $S$. leprosula dengan jarak tanam $4 \mathrm{~m} \mathrm{x} 4 \mathrm{~m}$ memiliki jumlah jenis tertinggi sedangkan jumlah individu tertinggi dimiliki oleh plot $2 \mathrm{~m}$ x $2 \mathrm{~m}$. Pada jarak tanam $2 \mathrm{~m} \times 2 \mathrm{~m}$, intensitas cahaya pada plot penelitian relatif rendah dan kelembaban yang tinggi. Per-tumbuhan ektomikoriza dipengaruhi oleh intensitas cahaya, kelembapan, serasah, bahan organik, biomassa, dan keter-sediaan unsur hara (Handayani, Riniarti, \& Bintoro, 2018; Herdina et al., 2013).

Umumnya, pada kondisi tanah yang asam sebagian besar akar dari jenis-jenis dipterokarpa bersimbiosis dengan fungi ektomikoriza, sehingga tanaman dapat tumbuh, berkembang dan bertahan hidup. Kondisi kemasaman tanah digambarkan dengan nilai $\mathrm{pH}$. Salah satu faktor adanya kemasaman tanah disebabkan oleh curah hujan yang tinggi (Suharno, Irawan, Qomariah, Putri, \& Sufaati, 2014; Tsumura, Kado, Yoshida, Abe, Ohtani, \& Taguchi, 2011).

Pada lahan yang tidak ditanami meranti diperoleh data pengamatan bahwa tidak ditemukan satu individu ektomikoriza jenis apapun. Dari kondisi ini terlihat jelas bahwa keberadaan ektomikoriza sangat berkorelasi dengan terbentuknya tegakan meranti yang terbangun sebagai hasil kegiatan restorasi lebih dari 20 tahun yang lalu. Dalam hal ini, perkembangan dan pertumbuhan vegetasi restorasi diikuti oleh perkembangan komunitas ektomikoriza edafis pada lokasi penelitian.

Terbentuknya tubuh buah di atas permukaan tanah tidak selalu menggambarkan keberadaan ektomikoriza di dalam tanah. Beberapa jenis ektomikoriza 
mampu membentuk tubuh buah di atas tanah dan di bawah tanah (Hakim et al., 2019; Herdina et al., 2013). Selain itu, musim juga sangat memengaruhi keberadaan dan perkembangan tubuh buah (basidiocarp). Umumnya, pada saat awal dan akhir musim hujan tubuh buah lebih banyak dijumpai (Karmilasanti, \& Maharani, 2016). Hasil identifikasi tubuh buah ektomikoriza secara morfologi umumnya hanya bisa sampai tingkat Genus. Identifikasi yang lebih spesifik disarankan untuk menggunakan marka molekuler. Hasil identifikasi morfologi tubuh buah pada plot penelitian disajikan pada Tabel 5.

Umumnya di hutan alam, keragaman jenis mikoriza yang ditemukan lebih tinggi dibandingkan di hutan buatan (Bechem, \& Alexander, 2012; Tarmeji et al., 2018). Pada penelitian ini, ditemukan 10 jenis dengan genus Russula, Laccaria, Amanita, dan Scleroderma. Genus Russula mendominasi di berbagai petak pengamatan. Fungi ektomikoriza pada berbagai tegakan S. leprosula ditunjukkan pada Gambar 2.

Tabel (Table) 4. Jumlah individu, jenis, dan suku ektomikoriza (Number of individuals, species, and family of ectomychorrizae)

\begin{tabular}{ccccc}
\hline No & $\begin{array}{c}\text { Jarak tanam } \\
\text { (Spacing distance) }\end{array}$ & $\begin{array}{c}\text { Jumlah jenis } \\
\text { (Number of species) }\end{array}$ & $\begin{array}{c}\text { Jumlah suku (Number } \\
\text { of Family) }\end{array}$ & $\begin{array}{c}\text { Jumlah individu } \\
\text { (Number of Individual) }\end{array}$ \\
\hline 1 & $2 \mathrm{~m} \times 2 \mathrm{~m}$ & 5 & 2 & 75 \\
2 & $3 \mathrm{~m} \times 3 \mathrm{~m}$ & 3 & 1 & 49 \\
3 & $4 \mathrm{~m} \times 4 \mathrm{~m}$ & 7 & 4 & 62 \\
4 & $5 \mathrm{~m} \times 5 \mathrm{~m}$ & 4 & 2 & 38 \\
5 & Kontrol & 0 & 0 & 0 \\
& $($ Control $)$ & & & \\
\hline
\end{tabular}

Tabel (Table) 5. Keberadaan populasi tubuh buah fungi ektomikoriza (The presence of ectomychorrizae fruit body population)

\begin{tabular}{|c|c|c|c|c|c|c|}
\hline \multirow[b]{2}{*}{ No } & \multirow{2}{*}{$\begin{array}{c}\text { Jenis } \\
\text { (Species) }\end{array}$} & \multicolumn{5}{|c|}{ Jarak tanam (Spacing distance) } \\
\hline & & $2 \mathrm{~m} \times 2 \mathrm{~m}$ & $3 \mathrm{~m} \times 3 \mathrm{~m}$ & $4 \mathrm{~m} \times 4 \mathrm{~m}$ & $5 \mathrm{~m} \times 5 \mathrm{~m}$ & $\begin{array}{c}\text { Kontrol } \\
\text { (Control) }\end{array}$ \\
\hline 1 & Russula $\mathrm{sp1}$ & $\checkmark$ & - & $\checkmark$ & - & - \\
\hline 2 & Russula $\mathrm{sp} 2$ & $\checkmark$ & $\checkmark$ & $\checkmark$ & $\checkmark$ & - \\
\hline 3 & Russula sp3 & - & $\checkmark$ & $\checkmark$ & $\checkmark$ & - \\
\hline 4 & Russula sp4 & $\checkmark$ & - & - & $\checkmark$ & - \\
\hline 5 & Russula sp5 & $\checkmark$ & $\checkmark$ & $\checkmark$ & $\checkmark$ & - \\
\hline 6 & Laccaria sp1 & $\checkmark$ & - & - & - & - \\
\hline 7 & Laccaria sp2 & - & - & $\checkmark$ & - & - \\
\hline 8 & Amanita sp. & - & - & $\checkmark$ & - & - \\
\hline 9 & Scleroderma sp1 & - & - & $\checkmark$ & - & - \\
\hline 10 & Scleroderma sp2 & - & - & - & $\checkmark$ & - \\
\hline
\end{tabular}




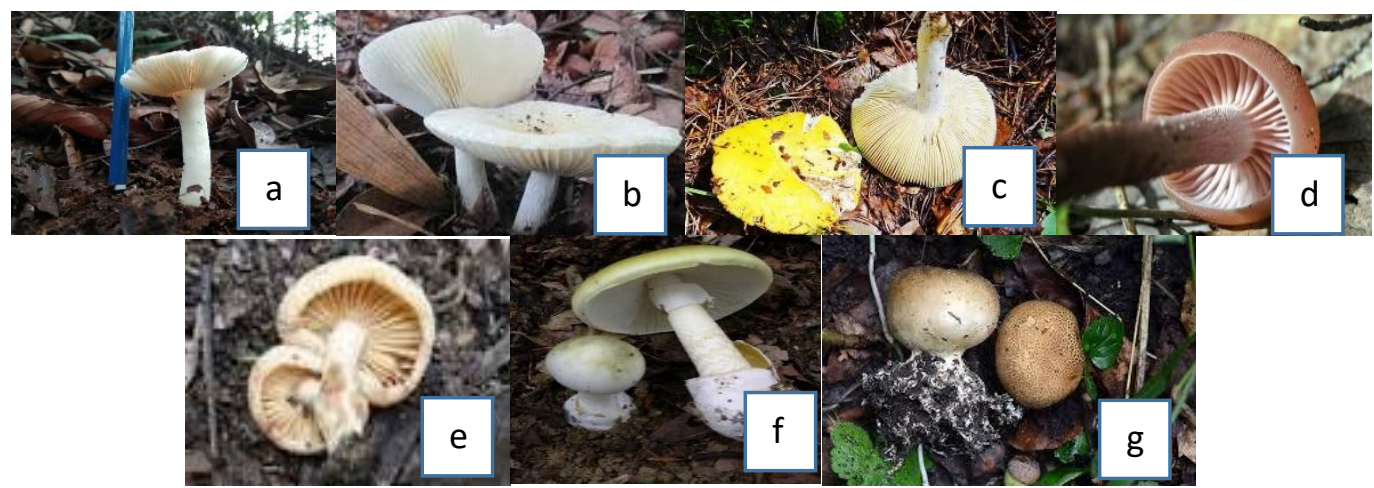

Gambar(Figure) 2. Identifikasi tubuh buah ektomikoriza (Identification of ectomycorrhizae's fruit body) a) Russula sp2; b) Russula sp3; c) Russula sp1 \& Russula sp4; d) Russula sp5; e) Laccaria sp1 \& Laccaria sp2; f) Amanita sp; g) Scleroderma sp1\& Scleroderma sp2

Hasil pengamatan ektomikoriza di lapangan menunjukkan bahwa tubuh buah fungi ektomikoriza yang ditemukan di HPGD bervariasi dalam bentuk, ukuran (panjang dan diameter), warna, batang, tudung, tekstur, dan lamela. Kesulitan dalam mengidentifikasi fungi ektomikoriza yang dijumpai adalah masih ada beberapa fungi yang masih muda dan belum berkembang sempurna terutama pada fungi yang berbentuk payung. Jenisjenis dari Russula sp. merupakan fungi ektomikoriza yang paling banyak dijumpai pada petak pengamatan. Russula sp2 (Gambar 2a) memiliki tudung fungi yang halus berwarna putih hingga merah muda, batang berwarna putih dan halus berukuran berkisar antara $5-10 \mathrm{~cm}$. Russula sp3 (Gambar 2b) yang ditemukan berukuran panjang batang berikisar antara $7-18 \mathrm{~cm}$ dengan diameter tudung berkisar antara $5-15 \mathrm{~cm}$. Batang fungi halus dengan warna putih, tudung berwarna putih, hidup secara berkoloni dan menempel dengan tanah (institious). Bentuk lamela memita dan rapat. Russula sp1 \& Russula sp4 (Gambar 2c) memiliki kesamaan yaitu memiliki tudung berwarna kuning. Batang fungi halus dan berukuran $5-10 \mathrm{~cm}$. Perbedaannya terletak pada diameter tudung, ukuran, dan terdapat bercak hitam pada Russula sp4. Jenis Russula sp5 (Gambar 2d) memiliki warna tudung putih kecoklatan, bentuk lamela yang rapat, batang fungi kasar dan berwarna kecoklatan memiliki panjang berkisar $5-8 \mathrm{~cm}$, dan hidup secara berkoloni.

Jenis Laccaria sp. (Gambar 2e) termasuk dalam famili Hydnangiceae, memiliki tudung dengan permukaan yang kasar dan berwarna coklat. Laccaria sp. yang ditemukan berukuran panjang batang berkisar antara $4-9 \mathrm{~cm}$ dan berbatang halus dengan diameter tudung berkisar antara $3-5 \mathrm{~cm}$. Laccaria sp. memiliki daging tudung yang tipis. Fungi ini hidup secara koloni dan menempel di tanah. Perbedaan dari Laccaria sp1 \& Laccaria sp2 yaitu pada tingkat warna, kematangan tubuh buah, ukuran, dan tingkat kekasaran tudung. Jenis Amanita sp. (Gambar 2f) memiliki ukuran diameter tudung berkisar antara $15-17 \mathrm{~cm}$ dengan panjang batang berkisar antara $14-17 \mathrm{~cm}$. Tudung fungi berwarna kuning terang dengan permukaan yang halus. Batang fungi berwarna putih dan memiliki cincin di tengah-tengah batang. Fungi ini hidup soliter. Jenis Scleroderma sp. (Gambar $2 \mathrm{~g}$ ) merupakan salah satu fungi yang berbentuk puffballs/bola. Scleroderma sp. yang ditemukan memiliki permukaan yang kasar beralur, berwarna kekuningan, coklat terang sampai dengan coklat gelap, dan ditemukan menempel pada tanah (institious) serta hidup berkoloni. Fungi ini memiliki ukuran diameter berkisar antara $2-4 \mathrm{~cm}$. Hampir semua Scleroderma sp. yang ditemukan memiliki 
akar dan jika puffballs dibelah maka akan berwarna hitam keabu-abuan. Perbedaan antara Scleroderma sp1 \& Scleroderma sp2 terletak pada warna, ukuran, bentuk batang, dan tingkat kekasaran. Penampakan tubuh buah ektomikoriza juga ditunjukkan pada Gambar 3.

Setiap jenis yang berada dalam satu genus dan satu famili memiliki banyak kemiripan. Umumnya tubuh buah fungi bisa tumbuh berkelompok, kecuali jenisjenis Amanita yang biasanya tumbuh secara soliter, sehingga hanya ditemukan satu jenis Amanita yang hanya terdapat pada jarak tanam $4 \mathrm{~m} \mathrm{x} 4 \mathrm{~m}$. Seluruh genus dari ektomikoriza yang ditemukan pada penelitian ini berada pada jarak tanam $4 \mathrm{~m}$ x $4 \mathrm{~m}$. Laccaria dan Scleroderma merupakan ektomikoriza yang tahan terhadap kekeringan tanah (Hustad, Meiners, \& Metthven, 2011). Oleh karenanya, kedua jenis ini dapat digunakan pada areal reboisasi, sehingga saat musim kemarau, tanaman dapat bertahan karena adanya simbiosis dengan fungi tersebut. Laccaria dan Scleroderma banyak ditemukan di HPGD hal tersebut dikarenakan kedua genus ini berkembang dengan baik pada suhu $25-29{ }^{\circ} \mathrm{C}$. Scleroderma sp. mengandung spora lebih banyak dibandingkan dengan jenis ektomikoriza yang berbentuk payung. Umumnya Scleroderma sp. memiliki kulit luar yang tebal sehingga lebih tahan terhadap kondisi lingkungan yang kurang menguntungkan (Brundrett et al., 1996).

Russula merupakan genus yang paling dominan ditemukan. Genus Russula mudah diidentifikasi dan ditemukan saat di lapangan karena umumnya Russula memiliki tudung yang berwarna cerah. Namun demikian untuk mengidentifikasi Russula hingga tingkat spesies cukup sulit dilakukan karena masih kurangnya laporan ilmiah maupun penelitian mengenai Russula (Chalermpongse, 1992; Noor, \& Rasidan, 2013). Chalermpongse (1992) juga melaporkan dominan Russula di hutan dipterokarpa di Thailand.

Tipe hutan dan habitat sangat berpengaruh terhadap keragaman ektomikoriza di suatu tempat. Hal ini dapat terjadi karena adanya perbedaan kondisi seperti komposisi jenis tumbuhan pohon dan struktur ekosistem hutan, umur hutan, pengaruh antropogenik (eksploitasi kayu, koleksi badan buah), faktor iklim, dekomposisi substrat kayu dan lain sebagainya (Diagne et al., 2013; Kunarso, \& Azwar, 2013; Sadili, 2010; Turjaman et al., 2005). Kanopi hutan berpengaruh terhadap peningkatan keragaman ektomikoriza, dan menurunkan fungi saprofitik (Brearley, 2012; Suharno et al., 2014; Widyati, 2013).

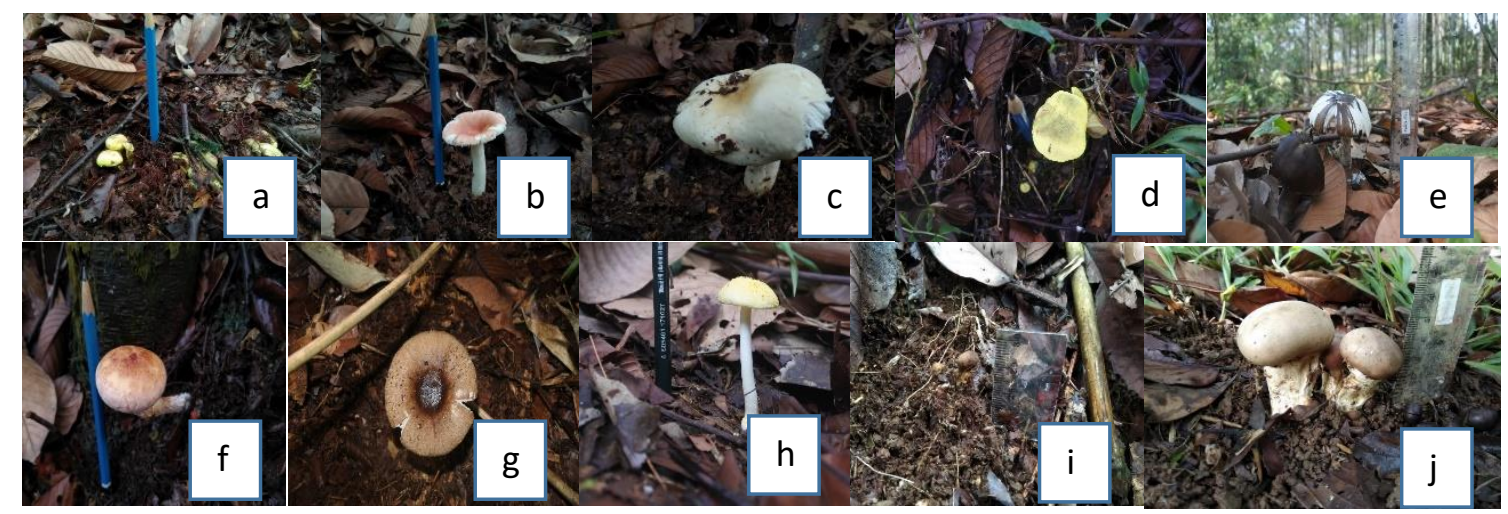

Gambar (Figure) 3. Ektomikoriza pada berbagai tegakan S. leprosula (Ectomycorrhizae on various stands of $S$. leprosula) a) Russula sp1; b) Russula sp2; c) Russula sp3; d) Russula sp4; e) Russula sp5; f) Laccaria sp1; g) Laccaria sp2; h) Amanita sp; i) Scleroderma sp1; j) Scleroderma sp2. 
Tabel (Table) 6. Nilai indeks kekayaan jenis (DMg), indeks keanekaragaman jenis (H'), dan indeks kemerataan jenis (E) ektomikoriza (The value of species richness index $(D M g)$, species diversity index $\left(H^{\prime}\right)$, and species evenness index (E) of ectomycorrhizae)

\begin{tabular}{ccrrr}
\hline No & $\begin{array}{c}\text { Jarak tanam } \\
(\text { Spacing distance })\end{array}$ & DMg & H' & E \\
\hline 1 & $2 \mathrm{~m} \times 2 \mathrm{~m}$ & 0,926 & 1,089 & 0,676 \\
2 & $3 \mathrm{~m} \times 3 \mathrm{~m}$ & 0,514 & 0,650 & 0,592 \\
3 & $4 \mathrm{~m} \times 4 \mathrm{~m}$ & 1,454 & 0,424 & 0,218 \\
4 & $5 \mathrm{~m} \times 5 \mathrm{~m}$ & 0,825 & 1,239 & 0,894 \\
5 & Kontrol (Control) & 0 & 0 & 0 \\
\hline
\end{tabular}

Tubuh buah fungi ektomikoriza yang ditemukan pada HPGD termasuk dalam divisi Basidiomycota. Pada penelitian Sato et al. (2015) menyatakan bahwa keanekaragaman Basidiomycota lebih rendah dibandingkan Ascomycota. Basidiomycota di hutan hujan tropis tidak terlalu tinggi dibandingkan pada hutan beriklim dingin dan hangat. Hasil penelitian Sato et al. (2015) yang dilakukan secara molekuler, menunjukkan bahwa Basidiomycota memiliki preferensi inang yang jelas bagi Dipterokarpa. Umumnya memilki preferensi pada tingkat genus dibandingkan pada tingkat spesies. Faktor lain yang memengaruhi keber-adaan dari fungi ektomikoriza seperti faktor edafik. Untuk melihat keragaman ektomikoriza dapat dihitung Indeks kekayaan jenis, keanekaragaman jenis, dan kemerataan jenis ektomikoriza pada petak pengamatan, yang disajikan pada Tabel 6.

Menurut Magurran (2004), kategori dari indeks kekayaan (DMg) memiliki nilai $\mathrm{DMg} \leq 3,5$ (rendah), 3,5 $\leq \mathrm{DMg} \geq 5$ (sedang), DMg > 5 (tinggi). Kategori keanekaragaman jenis $\left(\mathrm{H}^{\prime}\right)$ memiliki nilai $\mathrm{H}^{\prime} \leq 1,5$ (rendah), 1,5 $\leq \mathrm{H}^{\prime} \geq 3,5$ (sedang), $\mathrm{H}^{\prime}>3,5$ (tinggi). Kategori kemerataan jenis apabila berada pada nilai $0,20 \leq \mathrm{E} \geq$ 1 dapat dikatakan kondisi penyebaran jenis relatif stabil.

Kekayaan jenis tertinggi ditemukan pada jarak tanam $4 \mathrm{~m} \mathrm{x} 4 \mathrm{~m}$ dengan nilai 1,454 (tergolong rendah). Sedangkan nilai keanekaragaman jenis dan kemerataan jenis yang paling tinggi ditemukan pada jarak tanam $5 \mathrm{~m}$ x $5 \mathrm{~m}$ dengan nilai 1,239 (tergolong rendah) dan 0,894 (tergolong tinggi). Kemerataan jenis didukung oleh kondisi lingkungan dari masing-masing tegakan yaitu suhu, kelembapan dan intensitas cahaya serta kemampuan adaptasi dari ektomikoriza itu sendiri. Nilai kemerataan menunjukkan pola sebaran suatu jenis dalam suatu komunitas, semakin besar nilainya maka akan semakin seimbang pola sebaran suatu jenis di dalam komunitas begitu pula sebaliknya (Angi, \& Wiati, 2017; Atmoko et al., 2010; Destaranti et al., 2017). Penelitian Helbert, Turjaman \& Nara (2019), menyebutkan bahwa identifikasi ektomikoriza akan memiliki tingkat akurasi yang jauh lebih tinggi jika dilakukan secara molekuler.

\section{KESIMPULAN DAN SARAN}

\section{A. Kesimpulan}

Terdapat 13 jenis makrofauna dan mesofauna serta 10 jenis populasi tubuh buah fungi ektomikoriza di Hutan Penelitian Gunung Dahu (HPGD). Pertumbuhan dan perkembangan vegetasi yang ditanam sejalan dengan pertumbuhan dan perkembangan komunitas edafis di dalamnya (makrofauna dan mesofauna, ektomikoriza). Hal ini dibuktikan dengan kondisi pada petak pengamatan $S$. leprosula memiliki keragaman makrofauna, merofauna, dan ektomikoriza lebih tinggi dibandingkan pada petak kontrol. 


\section{B. Saran}

Identifikasi yang lebih spesifik untuk jenis ektomikoriza yang tumbuh di HPGD diperlukan sebagai data dasar dalam pengelolaan hutan penelitian lebih lanjut. Studi lanjutan untuk identifikasi yang lebih spesifik tentang ektomikoriza yang berasosiasi dengan tanaman meranti bisa dilakukan dengan menggunakan teknik identifikasi jenis secara molekuler. Pengamatan perlu dilakukan secara frekuentif pada berbagai musim untuk melihat dinamika populasi.

\section{UCAPAN TERIMA KASIH}

Penulis mengucapkan terima kasih kepada Atikah sebagai teknisi Laboratorium Pengaruh Hutan - Fakultas Kehutanan IPB dan Tuti sebagai teknisi Laboratorium Entomologi Hutan - Fakultas Kehutanan IPB atas keterlibatan dalam membantu penelitian ini. Terima kasih juga disampaikan kepada institusi Pusat Penelitian dan Pengembangan Hutan, Badan Penelitian Pengembangan dan Inovasi, Kementerian Lingkungan Hidup dan Kehutanan (KLHK), atas ijin penelitian di Hutan Penelitian Gunung Dahu.

\section{DAFTAR PUSTAKA}

(2014). Termites: the neglected soil engineers of tropical soils. Soil Science, 181(3/4), 157-165.

Achmad, S.R, \& Aji. (2016). Pertumbuhan tanaman karet belum menghasilakan di lahan pesisir pantai dan upaya pengelolaan di Kebun Balang, Jawa Tengah. Warta Perkaretan, 35(1), 11-24.

Alamsjah, F., \& Husin, E. (2010). Keanekaragaman fungsi ektomikoriza di rizosfer tanaman meranti (Shorea sp.) di Sumatera Barat. Biospectrum, 6(3), 155-160.

Amazonas, N., Viani, R., Rego, M., Camargo, F., Fujihara, R., Valsechi, O. (2018). Soil macrofauna density and diversity across a chronosequence of tropical forest restoration in Southeastern Brazil. Braz. J. Biol, 78(3), 449-456.

Angi, E.M., \& Wiati, C.B. (2017). Kajian ekonomi politik deforestasi dan degradasi hutan dan lahan kabupaten Paser, Kalimantan Timur. Jurnal Penelitian Ekosistem Dipterocarpa, 3(2), 63-80.

Anwar, K.E., \& Ginting, B.C.R. (2013). Mengenal Fauna Tanah dan Cara Identifikasinya. Jakarta: IAARD Press.

Apriyadi, R. (2014). Struktur Populasi semut invasif Anoplolepis gracilipes Smith (Hymenoptera: Formicidae) di Kebun Raya Bogor. (Thesis Master). Institut Pertanian Bogor, Bogor.

Ardhana, K. (2011). Manajemen Sumber Daya Manusia. Denpasar: Graha Ilmu.

Arief, A. (2001). Hutan \& Kehutanan. Yogyakarta: Kanisius.

Araújo, R., Fernandes, M., Paulo, A.C., Gomes, A. (2010). Biology of human hair: know your hair to control it. Adv Biochem engine/Biotechnol. Springer Verlag Berlin Heidelberg.

Atmoko, T., Arifin, Z., Priyono. (2010). Struktur dan sebaran tegakan dipterocarpaceae di sumber benih merapit, Kalimantan Tengah. Jurnal Penelitian Hutan dan Konservasi Alam, 8(3), 399-413.

Barbour, G., Burk, Pitts. (1987). Terrestrial Plant Ecology. New York: The Benyamin/Cummings Publishing Company, Inc.

Bautista, F., Castelazo, D.C., Robles, G.M. (2009). Changes in soil macrofauna in agroecosystems derived from low deciduous tropical forest on leptosols from karstic zones. Tropical and Subtropical Agroecosystems, 10, 185-197.

Bechem, E.E.T., \& Alexander, I.J. (2012). Phosphorus nutrition of 
ectomycorrhizal Gnetum africanum plantlets from Cameroon.

Brearley, F. (2012). Ectomycorrhizal Associations of the Dipterocarpaceae. Biotropica, 44(5), 637-648.

Brundrett, M., Bougher, N., Dell, B., Grove, T., Malajczuk, N. (1996). Working with Mycorrhizae in Forestry and Agriculture. Australia: Monograph ACIAR.

Borror, D.J., Triplehorn, C.A., Johnson, N.F. (1996). Pengenalan Pelajaran Serangga Edisi ke-6. Yogyakarta: Gajahmada Univ Press.

Cahyani, K., Aminatun, T., Putra, N. (2017). Struktur komunitas collembolan di lingkungan rhizosfer Chromolaena odorata pada lahan vulkanik, pantai berpasir, dan karst. Jurnal Prodi Biologi, 6(8), 455-464.

Chalermpongse, A. (1992). Biodiversity of ectomycorrhizal fungi in the dipterocarp forest of Thailand. Proceedings of Tsukuba Workshop in Tsukuba Science City. Biotechnology Assisted Reforestation Project (BioRefor)-IUFRO/SPDC. (hal. 143-153).

Destaranti, N., Sulistyani, Yani, E. (2017). Struktur dan vegetasi tumbuhan bawah pada tegakan pinus di RPH Kalirajut dan RPH Baturraden Banyumas. Scripta Biologica, 4(3), 155-160.

Diagne, N., Thioulouse, J., Sanguin, H., Prin, Y., Krasova-Wade, T., Sylla, S., Duponnois, R. (2013). Ectomycorrhizal diversity enhances growth and nitrogen fixation of Acacia mangium seedlings. Soil Biology and Biochemistry, 57, 468476.

Erizilina, E., Pamoengkas, P., Darwo. (2019). Hubungan sifat fisik dan kimia tanah dengan pertumbuhan meranti merah di KHDTK Haurbenters. Jurnal Pengelolaan Sumberdaya Alam dan Lingkungan, 9(1), 68-74.
Firmansyah, M.A., Suparman, Harimin, Wigena, I.G.P., Subowo. (2014). Karakterisasi populasi dan potensi cacing tanah untuk pakan ternak dari tepi sungai kahayan dan barito. Berita Biologi, 13(3), 333-341.

Fuady, Z., Satriawan, H., Mayani, N. (2014). Aliran permukaan, erosi dan hara sedimen akibat tindakan konservasi tanah vegetatif pada kelapa sawit. Jurnal Ilmu Tanah dan Agroklimatologi, 11(2), 95-103.

Gunawan, H., \& Prasetyo, B.L. (2013). Fragmentasi Hutan: Teori yang mendasari penataan ruang hutan menuju pembangunan berkelanjutan. Bogor: Pusat Penelitian dan Pengembangan Konservasi dan Rehabilitasi.

Hakim, S.S., Halwany, W., Rachmanadi, D. (2019). Fungi and soil macrofauna community in revegetated post-fire peatland in Central Kalimantan. Indonesian Journal of Forestry Research, 6(2), 107-116.

Haneda, F.N., \& Yuniar, N. (2015). Komunitas semut (Hymenoptera: Formicidae) pada empat tipe ekosistem yang berbeda di Desa Bungku Provinsi Jambi. Jurnal Silvikultur Tropika, 6(3), 203-209.

Handayani, I., Riniarti, M., Bintoro, A. (2018). Pengaruh dosis inokulum spora Scleroderma columnare terhadap kolonisasi ektomikoriza dan pertumbuhan semai damar mata kucing. Jurnal Sylva Lestari, 6(1), 915.

Hasyimuddin, Syahribulan, Usman, A.A. (2017). Peran ekologis serangga tanah di perkebunan Patallassang Kecamatan Patallassang Kabupaten Gowa Sulawesi Selatan. Biology for Life. Prosiding Seminar Nasional (hal.70-78).

Helbert, Turjaman, M., Nara, K. (2019). Ectomycorrhizal fungal communities of secondary tropical forests dominated by tristaniopsis in Bangka 
Island, Indonesia. PLOS ONE, 14(9), 1-9.

Herdina, J., Noli, Z., Chairul. (2013). Pertumbuhan beberapa tanaman untuk revegetasi yang diinokulasi ektomikoriza pada lahan bekas tambang batubara ombilin. Jurnal Biologika, 2(1), 47-58.

Hilwan, I., \& Handayani, P.E. (2013). Keanekaragaman mesofauna dan makrofauna tanah pada areal bekas tambang timah di kabupaten Belitung, Provinsi Kepulauan Bangka Belitung. Jurnal Silvikultur Tropika, 4(1), 35-41.

Hölldobler, B., \& Wilson, E.O. (1990). The ants. Cambridge: The Belknap Press. Harvard University Press.

Husamah, Rahardjanto, A., Hudha, A.M. (2017). Ekologi Hewan Tanah. Malang: Universitas Muhammadiyah Malang.

Hustad, V.P., Meiners, Metthven. (2011). Terrestrial macrofungi of Illinois oldgrowth prairie groves. Am. Midl. Nat, $166,13-28$.

Ibrahim, H. (2014). Keanekaragaman Mesofauana Tanah Daerah Pertanian Apel Desa Tulungrejo Kecamatan Bumiaji Kota Batu Sebagai Bioindikator Kesuburan Tanah. Malang: UMM Press.

Jeffries, M.J. (1997). Biodiversity and Conservation. New York: Routledge.

Jouquet, P., Bottinelli, N., Shanbag, R.R., Bourguignoon, T., Traore, S., Abbasi, A.S.

Juniarti, T.K., Herawatiningsih, R., Burhanuddin. (2017). Keanekaragaman jenis meranti (Shorea spp.) pada areal IUPHHKHTI PT. Bhatara Alam Lestari Kabupaten Mempawah Kalimantan Barat. Jurnal Hutan Lestari, 5(4), 1079-1087.

Karmilasanti, \& Maharani, R. (2016). Keanekaragaman jenis jamur ektomikoriza pada ekosistem hutan dipterokarpa di KHDTK Labanan, Berau, Kalimantan Timur. Jurnal Penelitian Ekosistem Dipterokarpa, 2(2), 57-66.

Kasongat, H., Muzna, A.A., Gofur, Ponisri. (2019). Identifikasi dan kenaekargaman jenis jamur ektomikoriza pada hutan jati di Seram bagian timur. Median, 11(1), 39-46.

Kunarso, A., \& Azwar, F. (2013). Keragaman jenis tumbuhan bawah pada berbagai tegakan hutan tanaman di Benakat, Sumatera Selatan. Jurnal Penelitian Hutan Tanaman, 10(2), 85-98.

Laessoe, T., \& Lincoff, G. (1998). Mushrooms. London, England: DK Publishing.

Leksono, A.S. (2011). Keanekaragaman Hayati. Malang: UB Press.

Lestari, N. S., \& Suryanto. (2013). The Hidden Treasure of Labanan. Samarinda: Balai Besar Penelitian Dipterokarpa.

Lutfi, M., \& Antono, H.T. (2017). Estimasi stok karbon di kawasan penambangan akibat perubahan luas penutupan lahan terkait dengan REDD. Statistika, 14(1), 15-24.

Mahendra, F., Riniarti, M., Niswati, A. (2017). Populasi dan keanekargaman mesofauna serasah dan tanah akibat perubahan tutupan lahan di resort pemerihan Taman Nasional Bukit Barisan Selatan. EnviroScienteae, 13(2), 128-138.

Magurran, A.E. (2004). Measuring Biological Diversity. Malden: Blackwell Science.

Mardji, D. (2010). Identifikasi jenis jamur mikoriza di hutan alam dan lahan pasca tambang batu bara PT Turbaindo Coal Mining Muara Lawa. Jurnal Kehutanan Tropika Humida, 3(1), 42-53.

Maria, K., Manurung, T., Sisillia, L. (2016). Identifikasi jenis pohon famili dipterocarpaceae di kawasan 
arboretum sylva Universitas Tanjungpura Pontianak. Jurnal Hutan Lestari, 4(4), 527-534.

Margalef, R. (1958). Information Theory in Ecology. General System, 3, 56-71.

Martala, S., \& Maya, L. (2014). Kepadatan dan distribusi cacing tanah di areal arboretum Dipterocarpaceae 1.5 Ha Fakultas Kehutanan Universitas Lancang Kuning Pekanbaru. Jurnal Lectura 5(1), 1-14.

Ngatiman. (2014). Serangan rayap Coptotermes sp. pada tanaman meranti merah (Shorea leprosula Miq) di beberapa lokasi penanaman di Kalimantan Timur. Jurnal Penelitian Dipterokarpa, 8(1), 1-14.

Ngatiman, \& Cahyono, D.D.N. (2017). Serangan rayap Coptotermes sp. pada tanaman Shorea leprosula miq. di PT Suka Jaya Makmur, Kalimantan Barat. Jurnal Penelitian Ekosistem Dipterokarpa, 3(1), 33-42,

Nono, Diba, F., Fahrizal. (2017). Pemanfaatan hasil hutan bukan kayu oleh masyarakat di Desa Labian Ira'ang dan Desa Datah Diaan di Kabupaten Kapuas Hulu. Jurnal Hutan Lestari, 5(1), 76-87.

Noor, M., \& Saridan, A. (2013). Keanekaragaman fungi makro pada tegakan benih dipterocarpaceae di Taman Nasional Tanjung Puting dan Taman Nasional Sebangau Kalimantan Tengah. Jurnal Penelitian Dipterokarpa, 7(1), 53-62.

Nurrohman, E., Rahardjanto, A., Wahyuni, S. (2018). Studi hubungan keanekaragaman makrofauna tanah di perbukanan cokelat (Theobroma cacao L.) Kalibaru Banyuwangi. Bioeksperimen, 4(1), 1-10.

Patang, F. (2010). Keanekaragaman takson serangga dalam tanah pada areal bekas tambang batu bara PT. Mahakam Sumber Jaya Desa Separi Kutai Kartanegara - Kalimantan Timur. Bioprospek, 7(1), 80-89.
Peritika, Z.M., Sugiyarto, Sunarto. (2012). Diversity of soil macrofauna on different pattern of sloping land agroforestry in Wonogiri, Central Java. Biodiversitas, 13(3), 140-144.

Pranoto, D., \& Latifah, S. (2016). Pengaruh aktivitas rayap tanah terhadap produktivitas tanah di arboretum sylva Fakultas Kehutanan Untan. Jurnal Hutan Lestari, 4(4), 463-471.

Purwaningsih. (2004). Sebaran ekologi jenis-jenis Dipterocarpaceae di Indonesia. Biodiversitas, 5(2), 89-95.

Purwanto, E., Wawan, Wardati. (2017). Kelimpahan mesofauna tanah pada tegakan tanaman karet (Havea brasiliensis Muell. Arg) di tanah gambut yang ditumbuhi dan tidak ditumbuhi Mucuna bracteata. JOM FAPERTA, 4(1), 1-14.

Putra, M. (2012). Makrofauna Tanah pada Ultisol di Bawah Tegakan Berbagai Umur Kelapa Sawit (Elaeis guineensis Jacq.). Riau: UNRI Press.

Rachmat, H.H., \& Fambayun, R.A. (2019). Komatsu-Foerdia Conservation (KoFCo) nursery: an effort to support dipterocarps genetic conservation in Indonesia. Prosiding Seminar Nasional Masyarakat Biodiversitas Indonesia (hal.23-66).

Rachmat, H.H., Fambayun, A.R., Yulita, S.K., Susilowati, A. (2020). Ex-situ conservation and management of dipterocarps genetic resources through seedlings collections and nursery establishment. Biodiversitas, 21(2), 556-563.

Risman, \& Ikhsan, A. (2017). Penggambaran makrofauna dan mesofauna tanah dibawah tegakan karet (Hevea brazilliensis) di lahan gambut. JOM Faperta, 4(2), 1-15.

Rohmaya, Mardji, D., Sukartiningsih. (2011). Keanekaragaman jenis jamur ektomikoriza pada kondisi hutan dangan kelerengan yang berbeda di hutan wisata bukit Bangkirai PT 
Inhutani 1 Balikpapan. Jurnal Kehutanan Tropika Humida, 4(2), 150-160.

Sadili, A. (2010). Struktur dan komposisi jenis tumbuhan herba dan semai pada habitat satwa herbivor di Suaka Margasatwa Cikepuh, Sukabumi, Jawa Barat. Jurnal Berita Biologi, 10(1), 1-10.

Sato, H., Tanabe, S.A., Toju, H. (2015). Contrasting diversity and host association of ectomycorrhizal basidiomycetes versus rootassociated ascomycetes in a dipterocarp rainforest. PLOS ONE, 10(4), 1-20.

Septria, D., Fernando, T., Tavita, G. (2018). Keanekaragaman jenis pohon famili dipterocarpaceae di hutan adat bukit benuah Kecamatan Sungai Ambawang Kabupaten Kubu Raya. Jurnal Hutan Lestari, 6(1), 114-122.

Simanjuntak, A.K \& Waluyo, J. (1982). Cacing Tanah Budidaya dan Pemanfaatannya. Jakarta: Penebar Swadaya.

Simatupang, B., Niswati, A., Yusnaini, S. (2015). Populasi dan keanekaragaman cacing tanah pada berbagai lokasi di hutan Taman Nasional Bukit Barisan Selatan (TNBBS). J. Agrotek. Tropika, 3(3), 402-408.

Subiakto, A., \& Sakai, C. (2007). Manajemen Persemaian KOFFCO System. Bogor: Pusat Penelitian dan Pengembangan Hutan dan Konservasi Alam.

Subiakto, A., Rachmat, H.H., Sakai, C. (2016). Choosing native tree species for establishing man-made forest: A new perspective for sustainable forest management in changing world. Biodiversitas, 17(2), 620-625.

Sugiyarto. (2000). Keanekaragaman makrofauna tanah pada berbagai umur tegakan sengon di RPH Jatirejo, Kabupaten Kediri. Biodiversitas, 1(2), 47-53.
Sugiyarto, Efendi, M., Mahajoeno, E., Sugiti, Y., Handayanto, E., Agustina, L. (2007). Preferensi berbagai jenis makrofauna tanah terhadap sisa bahan organik tanaman pada intesitas cahaya yang berbeda. Biodiversitas, 7(4), 96-100.

Suharno, Irawan, C., Qomariah, E., Putri, I., Sufaati, S. (2014). Keragaman makrofungi di Distrik Warmare Kabupaten Manokwari, Papua Barat. Jurnal Biologi Papua, 6(1), 38-46.

Suin, N.M. (2012). Ekologi Hewan Tanah. Bandung: Bumi Aksara.

Sukarno, N., Listiyowati, S., Rahayu, N., Nara, K. (2019). Elaphomyces tropicalis sp. nov.: A new ectomycorrhizal fungus associated with dipterocarps from tropical Indonesia. Mycoscience, 60(2019), 83-88.

Sutoyo. (2010). Keanekaragaman hayati Indonesia suatu tinjauan: masalah dan pemecahannya. Buana Sains, 10(2), 101-106.

Tarmeji, A., Shanti, R., Patmawati. (2018). Hubungan bahan organik dengan keberadaan fauna tanah pada umur rehabilitasi lahan pasca tambang yang berbeda. Jurnal Agroekoteknologi Tropika Lembab, 1(1), 1-10.

Turjaman, M., Tamai, Y., Segah, H., Limin, S., Cha, J.Y., Osaki, M., Tawaraya, K. (2005). Inoculation with the ectomycorrhizal fungi Pisolithus arhizus and Scleroderma sp. Improves early growth of Shorea pinanga nursery seedlings. New Forest, 30, 67-73.

Tsumura, Y., Kado, T., Yoshida, K., Abe, H., Ohtani, M., Taguchi, Y. (2011). Molecular phylogeny database for classifying Shorea species (Dipterocarpaceae) and techniques for checking the legitimacy of timber and wood products. Journal of Plant Research, 124, 35-48. 
Ulfa, M., Faridah, E., Lee, S., Sumardi, Roux, C., Galiana, A., Mansor, P., Ducousso, M. (2019). Multi inang fungi ektomikoriza pada dipterocarpaceae di hutan tropis. Jurnal Ilmu Kehutanan, 13, 56-69.

Vasconcellos, R.L.F., Segat, J.C., Bonfirm, J.A., Baretta, D., Cardoso, E.J.B.N. (2013). Soil macrofauna as an indicator of soil quality in an undisturbed riparian forest and recovering site of different ages. European Jurnal of Soil Biology, 58(2013), 105-112.

Wibowo, C., \& Slamet A.S. (2017). Keanekaragaman makrofauna tanah pada berbagai tipe tegakan di areal bekas tambang silika di Holcim
Educational Forest, Sukabumi, Jawa Barat. Jurnal Silvikultur Tropika, 8(1), 26-34.

Widyati, E. (2013). Pentingnya keragaman fungsional organisme tanah terhadap produktivitas lahan. Tekno Hutan Tanaman, 6(1), 29-37.

Wihartono, M. (2015). Kawasan tropis pegunungan sebagai kawasan rawan bencana dengan nilai ekologi tinggi dan upaya pelestariannya. Jurnal Bionature 16(1), 1-7.

Wortley, L., Hero, J. M., Howes, M. (2013). Evaluating ecological restoration success: a review of the literature. Restoration Ecology, 5, 537-543. 